\title{
Donating Time or Money? The Effects of Religiosity and Social Capital on Civic Engagement in Qatar
}

DOI:

10.1007/s11205-017-1646-9

\section{Document Version}

Accepted author manuscript

Link to publication record in Manchester Research Explorer

\section{Citation for published version (APA):}

Diop, A., Johnston, T., Le, K. T., \& Li, Y. (2017). Donating Time or Money? The Effects of Religiosity and Social Capital on Civic Engagement in Qatar. Social Indicators Research. https://doi.org/10.1007/s11205-017-1646-9

\section{Published in:}

Social Indicators Research

\section{Citing this paper}

Please note that where the full-text provided on Manchester Research Explorer is the Author Accepted Manuscript or Proof version this may differ from the final Published version. If citing, it is advised that you check and use the publisher's definitive version.

\section{General rights}

Copyright and moral rights for the publications made accessible in the Research Explorer are retained by the authors and/or other copyright owners and it is a condition of accessing publications that users recognise and abide by the legal requirements associated with these rights.

\section{Takedown policy}

If you believe that this document breaches copyright please refer to the University of Manchester's Takedown Procedures [http://man.ac.uk/04Y6Bo] or contact uml.scholarlycommunications@manchester.ac.uk providing relevant details, so we can investigate your claim.

\section{OPEN ACCESS}




\title{
Donating Time or Money? The Effects of Religiosity and Social Capital on Civic Engagement in Qatar
}

\author{
Abdoulaye Diop (Ph.D.) \\ Associate Research Professor - Head of Research Dept. \\ Social and Economic Survey Research Institute (SESRI) \\ Qatar University \\ P.O.Box 2713 Doha Qatar \\ $\mathrm{T}+97444033029$ (direct) \\ $\mathrm{T}+97444033020$ (reception) \\ F+974 44033021 \\ adiop@qu.edu.qa \\ Kien Trung Le \\ Associate Research Professor \\ Social and Economic Survey Research Institute (SESRI) \\ Qatar University \\ P.O.Box 2713 Doha Qatar \\ $\mathrm{T}+97444033034$ (direct) \\ $\mathrm{T}+97444033020$ (reception) \\ F+974 44033021 \\ kienle@qu.edu.qa \\ Trevor Johnston \\ Postdoctoral Research Fellow \\ The Middle East Initiative in the Belfer Center, \\ Harvard University Kennedy School of Government \\ trevorjohnst@gmail.com. \\ Yaojun Li \\ Professor of Sociology \\ Department of Sociology and Cathie Marsh Institute for Social Research \\ School of Social Sciences, Manchester University, UK \\ Tel: 00-44-2750274 \\ Yaojun.Li@manchester.ac.uk
}




\title{
Donating Time or Money? The Effects of Religiosity and Social Capital on Civic Engagement in Qatar
}

\begin{abstract}
Few studies have examined the role of religiosity and social capital on civic engagement in the context of a Muslim country. In this paper, we explore the impact of religiosity and social capital on charitable donations and volunteerism in Qatar. Drawing on a nationally representative survey from Qatar, we consider various attitudinal and behavioral measures for capturing religiosity and social capital. The results indicate that, even after controlling for a wide range of demographic variables, behavioral measures have a stronger effect than attitudes. Individuals who regularly perform daily prayers are more likely to donate than those individuals who simply describe themselves as religious. Similarly, individuals who are more active in their neighborhood engagement are more likely to volunteer than those who merely report high levels of social trust. These results suggest that when it comes to the relationship between religiosity, social capital and civic engagement, individual behavior is much more predictive than attitudes alone. We also find that even in the case of Qatar, where citizen wealth has rapidly increased in the last few decades, there is little evidence of substitution effects: citizens do not appear to trade-off or substitute between time and money. Instead, more religious and active citizens are likely to do both.
\end{abstract}

\section{Introduction}

The influence of religion and social capital on political participation and civic engagement has been studied extensively in the US and Europe. Generally, scholars have found that involvement in civil society and religious organizations, such as the local church or synagogue, encourages both civic engagement and political participation. Spillover theory provides one possible explanation for this association, suggesting that as people become more involved in some activities (e.g., at their church), they will be more likely to participate in other activities as well (e.g., political and civic engagement). Existing studies have demonstrated a strong association between religiosity and political participation, volunteering, and philanthropy (Miller and Wattenberg 1984; Putnam 2000; Greeley 2001; Wuthnow 2003). More recent work has extended this logic to Islamic spaces of worship (Pfaff and Gill 2006), finding a similar trend between political participation and civic engagement around mosques (Jamal 2005; Dana and Barreto 2011; 
Li 2015a). Yet however persuasive these results, we know relatively little about how these relationships operate in the context of a Muslim-majority country. Do religiosity and social capital work in a similar way in Muslim countries? And what effect do these beliefs and practices have on volunteering time or making charitable donations?

Previous work on these questions has focused almost exclusively on the West, and has only obliquely addressed the role of Muslims within these countries. Extrapolating from these Western cases may be problematic given the distinct context of the Muslim world. In Muslim-majority states, the religious marketplace varies significantly from many Western countries, where pluralism and the separation of church and state largely define the relationship between personal faith, social trust and civic engagement. Moreover, in Muslim countries, the prevailing religious norms, beliefs and practices may differ starkly from those found in Western (i.e., Judeo-Christian) countries. Across such varying contexts, we cannot simply assume that the traditional relationships between religiosity, social capital and engagement will similarly hold. This paper explores these relationships, investigating the effects of religiosity and social capital on civic engagement in the Islamic world today.

In particular, we focus on charitable contributions and volunteering in the Arabian Gulf state of Qatar. For Qatar and much of the Gulf, opportunities for civic engagement are often limited to more traditional venues of participation (Gengler et. al. 2013). With broader political participation constrained, charities and other non-profit organizations represent one of the few spaces for civic engagement (Montagu 2010). Who participates in these organizations and how they do so (e.g., donating time or money) remains an open but crucial question to understanding the Islamic world in general, and the Gulf in particular. This question has been complicated by the major social and economic changes we have seen throughout the region. Perhaps more than anywhere else in the Islamic world, the Gulf has developed and transformed rapidly over the past few decades (Kamrava 2012). Before the discovery of oil, the Gulf was little more than a collection of small villages dependent on local commerce and other trades (e.g., pearling). After the discovery of oil, these villages have transformed into petro-states reliant on foreign labour. These once- 
homogenous populations have radically changed the compositions with the inflow of workers from Asia, the West and other parts of the Middle East.

At the same time, though, such economic development and social upheaval as has been witnessed in the Gulf countries in the last few decades has not necessarily brought new opportunities for political participation. The same tribal groups that ruled before the discovery of oil largely remain in power today. They continue to circumscribe the political space, leaving traditional civil society and charitable organizations in a rather vulnerable position. And with the growing debate over social and political participation in the Middle East today, the question of local civic engagement, however limited it may be, has taken on an increasing importance.

Hoping to better understand civic engagement in the Gulf, we focus on the case of Qatar, exploring the role that religious belief and social trust play in charitable donations and volunteerism. As the largest (per capita) gas exporter in the world, Qatar is one of the richest countries today with an estimated Gross Domestic Product (GDP) per capita of \$102,000 in 2013 (CIA 2014). This immense wealth of oil resource has led to a highly noticeable improvement in the citizens' welfare and quality of life. Such rapid development has had manifold implications for society. While the rentier system has been studied extensively by political economists (Beblawi 1987; Okruhlik 1999), there is little work that considers how this infusion of wealth has also affected more traditional social relationships, like the association between religiosity, social capital and civic engagement. Has this rapid development eroded support for charities and other nonprofit organizations? And to what extent does this wealth produce substitution effects, with volunteer time being replaced by financial donations?

In this paper, we explore these questions with original survey data from Qatar. Using both attitudinal and behavioral measures for religiosity and social capital, we consider the determinants of charitable giving and volunteerism in Qatar. To pre-empt ourselves somewhat, we find that the behavioral measures are much more predictive than simple attitudes, and that social capital at the neighborhood level is strongly associated with both donations and volunteerism. As participation in neighborhood activities increases, the likelihood of donation and volunteering also increases. While less robust, our behavioral measure of religiosity also appears to strongly predict 
volunteerism, but not donations. In this case, we find that individuals who perform their daily fajr prayers are more likely to volunteer than individuals who do not pray every day. Finally, we find little evidence that individuals are substituting money for time. Although an imperfect test of the substitution argument, our survey results suggest that for those Qataris who are active in charities and other non-profit organisations, there does not appear to be a trade-off between donating time and money; they do both.

The remainder of this paper will proceed as follows. In the next section, we briefly outline the existing literature on civic engagement in the West. This literature has produced a wealth of results and significant findings, which we use to tease out implications for Muslim-majority contexts and Qatar. Drawing on this discussion, the following section then describes the religious marketplace and socio-economic context of the Gulf. Compared to other areas of the Islamic world, Gulf countries present their own distinct contexts that complicate the study of civic engagement. We address these issues and consider their implications for Qatar. Having described the Gulf context in general and Qatar in particular, we then introduce our data and hypotheses. The penultimate section then provides a series of estimations, empirically testing the relationship between religiosity, social capital, and charitable donations and volunteering. Finally, we conclude with a broader discussion of the results and their implications for Gulf society during a period of rapid socio-economic change.

\section{Religiosity, Social Capital and Civic Engagement in the West}

Existing scholarship has produced a rich and well-developed literature on the relationship between religiosity and civic engagement. Scholars have long found that religious practice encourages civic engagement and political participation (Lam 2002; Schwadel 2005; Ruiter and De Graaf 2006; Bekkers and Schuyt 2008). Typically, this association has been explained in light

of spillover effect theory, which suggests that 'participation in one arena (the workplace) allows the individual to gain certain skills and self-confidence necessary to participate in other areas of social life' (Peterson 1992: 123-124). When applied to religious participation, we should expect 
that as individuals become more actively involved in the life of their religious institutions, they will also participate more in politics and other forms of civic engagement. Building on existing work, Lim and Putnam (2010) explore the positive relationship between religiosity and life satisfaction. They find evidence that individuals who regularly attend religious services tend to increase their social networks and build intra-congregation relationships. They argue that this effect underlies the association between religiosity and life satisfaction.

In a related vein, greater involvement in the church is highly associated with more political knowledge and higher levels of overall political participation and communal politics (Peterson 1992). Religious institutions are more than simply places of worship. They provide parishioners with a space to exchange information, to learn from one another, and to develop skills that may be valuable to participation in politics and other forms of civic engagement (Wuthnow 1999). As such, religious institutions become one of the main sources for spreading political information and inculcating civic ethics. However influential one's religious belief may be, it is these practices and related activities that may play the greatest role in socializing citizens, informing them about the relationship between faith, politics and engagement. This socializing influence is so powerful that we even see its effects in countries nominally defined by the separation of church and state. Miller and Wattenberg (1984) provide evidence that religion has played a major role in American politics, especially in electoral outcomes. Using data from the National Election Study (NES), they find that religiosity not only increases the likelihood of voter turnout, but also influences presidential vote choice.

Beyond electoral politics, religiosity has been found to contribute to other forms of civic engagement. Given the socialization process, religious people who frequently attend church services are more likely to be involved in other civic but non-political activities (Putnam 2000). According to him, 'churches provide an important incubator for civic skills, civic norms, community interests and civic recruitment' (Putnam 2000: 66). Because religious institutions tend to support a wide range of social activities that go beyond conventional worship (e.g., food kitchens, shelter for the homeless, and programmes for abused women and children), involvement in these organizations also tends to foster other types of civic engagement. In fact, some scholars 
suggest that the high level of religiosity and involvement in religious institutions among Americans citizens may help explain the gap in volunteering between the United States and other advanced industrial societies (Wuthnow 1999). ${ }^{1}$

Potentially mediating this relationship, if not substituting for religiosity altogether, is the effect of social capital on civic engagement. While defined in various ways (see Paxton 1999; Li 2015b), we can generally think of social capital as inter-communal trust or other resources arising from an individual's embeddedness within his or her personal networks and community relationships. As a form of trust, we tend to focus on social capital at local levels, where individuals interact with their families, friends and neighbors. In some cases, social capital and civic engagement are assumed to be roughly equivalent, or at least mutually constitutive. Here, however, we draw a distinction between local social capital, on the one hand, and broader engagement in civic organizations, on the other. Social capital reflects a general sense of trust and shared community, and can be thought of as a resource or endowment at the individual or community-level (Coleman 1988). Civic engagement, by contrast, is a behavioral outcome, representing an individual's choice to participate in organized groups. And for countries where political participation is constrained, these organizations may constitute one of the few spaces available for public engagement.

We consider how religiosity and social capital - as distinct characteristics - influence civic engagement. In this sense, we follow more closely in the work of Putnam and his distinction between involvement in religious and secular organizations. We can think of social capital as a more communal property, outside of explicitly religious structures or institutions. And just as spillover theory suggests religious participation will increase engagement, so too should we expect this relationship to hold for social capital. The relationship between social capital and religiosity is a complicated one. For some scholars, religious participation - and the bonds that it produces

\footnotetext{
${ }^{1}$ However, Wuthnow (1999) cautions researchers about the use of religious participation as a predictor of volunteering in the United States. He argues that because religious participation has remained almost the same over time, the decline in other forms of civic engagement cannot be simply explained by an eroding base in religion. He argues that the relationship between religious participation and civic engagement, as well as the composition of religious participation, may be changing and hence signaling future problems for civic engagement in the United States.
} 
among members - plays a critical role in the development of social capital, making these concepts intimately connected (Beyerlein and Hipp 2005).

Even if conceptually distinct, religious practice may in part produce social capital. Churches often encourage their members to participate in a range of charitable or philanthropic organizations, many of which may be secular. This participation, in turn, promotes broader ties and relationships outside the church, producing social capital and facilitating further civic engagement (Wuthnow 1999: 354). And the relationship between religiosity, social capital and civic engagement can be even more complicated when we consider congregational, devotional and theological differences (Lam 2002; Schwadel 2005). Recent work further suggests that church attendance may have heterogeneous effects, having a greater influence on some social groups than on others. For example, the relationship between church attendance and volunteering is more pronounced for black Americans than for white Americans (Musick, Wilson and Bynum 2000). To the extent that religiosity produces social capital, we should expect our empirical results to be biased against finding a significant effect for religiosity.

While the effects of religion on political participation and civic engagement have been studied extensively, much of this work has focused on the role of the church in Western countries. We have to be careful in generalizing from these studies, particularly with regards to distinct political and religious contexts. ${ }^{2}$ Relatively little attention has been given to the role and impact of mosques on Muslims' political participation and civic engagement, particularly in Muslim societies. Recently, scholars have begun to address this omission, particularly in light of the increasing importance of understanding the integration of Muslims in the United States and Europe. In the wake of September $11^{\text {th }}$, many American and European Muslims have found themselves subjected to prejudice and suspicion. In the US, citizens and politicians alike have questioned not only the role of mosques within American society, but also the loyalties and patriotism of American Muslims. Jamal (2005) demonstrates a positive association between

\footnotetext{
${ }^{2}$ A growing literature on religiosity and political behavior has shown how important it is that we take context seriously. Individual attitudes on democracy and corruption depend on a complex, conditional relationship between macro-political structures (e.g., a country's regime type) and an individual's local religious context (Bloom and Arikan 2012; Sommer, Bloom and Arikan 2013).
} 
mosque participation and civic involvement for both Arab and South Asian Muslims. This result, however, was not observed with the African American Muslims, leading Jamal to argue that the difference among these groups was driven by their distinct experiences in the United States.

Using more recent and diverse data from an original survey of Muslim Americans across eleven cities in the USA, Dana and Barreto (2011) argue that the effects of Masjids or mosques are no different than churches and synagogues. Not only are mosques associated with a higher level of civic engagement, but they also contribute to creating a more informed citizenry (Dana and Barreto 2011). They find that Muslims who are more involved with their mosques are also more likely to be actively involved in American politics. In addition, the authors argue that high religiosity among Muslim Americans is associated with the belief that Islam is compatible with the American political system.

Critically though, none of these studies explore the role of religiosity and social capital in Muslim-majority countries. Recent work by Sarkissian (2012) represents a major effort in this direction, investigating the determinants of civic engagement across nine Muslim-majority countries. Sarkissian finds strong evidence that religious participation increases engagement, while traditional measures of social capital have less influence. These results represent a major contribution in this literature, helping us understand how faith and trust influence engagement across the Islamic world. Focusing more on the effects on political opposition, Langohr's (2004) study of NGOs in Egypt, Tunisia and Palestine reveals the importance of civil society in creating a space for opposition voices. In such cases, political participation is highly circumscribed (particularly for Islamists), leaving civic associations one of the few channels available for organising and engaging in broader political life. Langohr offers an important corrective to critics who allege the Middle East lacks a vibrant civil society.

Absent in these studies, however, is any discussion of the Arabian Gulf. Given the Gulf's distinct political, economic, social and religious context, this omission is problematic. Even if these results hold in Arab states like Egypt and Tunisia, the modern Gulf offers a whole set of complicating and other confounding factors. Few studies on civil society have directly explored the rentier Gulf context. A notable exception is Montagu's (2010) excellent work on the voluntary 
sector in Saudi Arabia. She argues that civil society, including NGOs and other charitable associations, provide a space for the Saudi population to engage with their rulers and even express some forms of dissent. By creating such opportunities, this sector plays a vital role in the reform process in the kingdom. Saudi Arabia, however, represents a markedly different case than some of the smaller Gulf states, like Qatar. In the next section, we describe this distinct context and consider how these factors should influence the relationship between religiosity, social capital and engagement.

\section{The Religious Marketplace and Development Context of the Gulf}

The Islamic world is far from monolithic, varying widely from the Arab Middle East, to the Slavic Caucasus and the Asian East. Across (and even within) these regions, Islamic practice plays out in distinct ways. In some countries, Muslim practices even include a variety of preIslamic traditions and syncretic rituals or beliefs (Ringgren 2014: 8). These differences can be readily seen at the local level, where popular forms of Islam vary widely from those found predominantly in the Arab world. While Sufism continues to be practised throughout the Middle East and North Africa, most Arabs can be broadly classified as Sunni or Shia, and further disaggregated within these sects. In the Arabian Gulf, in particular, Islamic practice is often dogmatic, and more closely follows the Sunna and Hadith.

In addition to these differences in religious practice, Muslim-majority countries vary widely across a myriad of economic and social dimensions. The varying development and social contexts of these areas crucially inform how individuals conceptualize the relationship between personal faith, their place within the community, and the choice to participate in civic organizations. These socio-economic differences are consequential, and often as significant as the variations in religious practice. Structural economic factors and welfare systems can mediate the relationship between religiosity and civic engagement (Gill and Lundsgaarde 2004), confounding our analysis in important ways. 
Such variation is especially pronounced in the Middle East, where politically stable and resource-rich states (e.g., Qatar, the UAE) look quite different from their conflict-ridden and economically stagnant regional neighbors (e.g., Syria, Palestine, Yemen). Economic scarcity and conflict can undermine societal cohesion and disrupt the formation of social capital across society (Colletta and Cullen 2000), which may be critical to conflict resolution (Grootaert and Bastelaer 2001). And to the extent these conflicts fall along existing ethno-religious or socio-economic cleavages, it can further erode inter-communal trust. As such, we should expect civic engagement to vary significantly across these high- and low- conflict areas, making the effects of religiosity and social capital context-dependent (Bloom and Arikan 2012).

Each of these contexts presents their own complications for studying the determinants of civic engagement in Muslim-majority countries. However, challenging these conditions are, capturing this context is crucial to explaining the effects of religiosity and social capital. To this end, in the current paper we focus on a specific case and its context: the broader Arabian Gulf and Qatar, in particular. In the Arabian Gulf, the discovery of oil and gas financed a rapid development of the region, resulting in rapid state development and a massive transformation of society (Schwarz 2008). This transformation has had manifold effects on the populations of the Gulf, bringing millions of migrants to the region, many of whom hold different religious beliefs and social practices, which have at times clashed with natives (Nagy 2006). The explosion of wealth and increasing migration has challenged basic Gulf institutions, like the family unit and household dynamics (Gardner 2011). With these changes producing social segregation and increasingly insular communities, there is a real concern that Gulf society has been irrevocably transformed, with individuals retreating from the public and social space (Sobh and Belk 2011).

In other modernizing societies, these structural changes have had manifold effects on religiosity and social trust (Putnam, Campbell and Garrett 2012). Largely motivated by the Western experience, modernization theory suggests that as countries develop economically, problems of scarcity become less pronounced and post-materialist values begin to emerge, introducing a host of other social changes (Inglehart 1997). These changes have often represented a threat to traditional institutions like organized religion, re-shaping how individuals practice their 
faith, relate to one another, and even participate civically (Schofer and Fourcade-Gourinchas 2001). This process has been well-documented and empirically demonstrated in the West, but has been less successful in explaining the changes (or lack thereof) in the Middle East and other parts of the world (Norris and Inglehart 2002).

Qatar represents an ideal case-study for exploring these changing dynamics and enduring relationships within a rentier system. As the largest gas exporter per capita, and holding the third largest natural gas reserves, Qatar is one of the richest countries in the world today with an estimated Gross Domestic Product (GDP) per capita of \$102,000 in 2013 (CIA 2014). This wealth has come suddenly, bringing with it millions of migrant workers from Asia, Africa, and the Middle East (Shah 2013). Along with the smaller Western expatriate population, the growing presence of these workers has forced Qataris to re-examine their nation and their place within society. According to some critics, these demographic changes may have led Qataris to look inward, becoming more insular and less engaged civically or within their local communities and neighborhoods (Putnam 2007). These new groups have also brought with them their various religious traditions, introducing significant diversity in a country for which Islam has long been overwhelmingly dominant. To what extent these changes have reduced or encouraged engagement remains an open question, which we hope to partly answer here by focusing on Qatari charitable donations and volunteerism.

\section{Data and Hypotheses}

Our empirical analysis draws on data from the survey "From Fareej to Metropolis: A Social Capital Survey of Qatar," conducted by the Social and Economic Survey Research Institute (SESRI) at Qatar University, and was funded by the Qatar Foundation. The survey interviewed representative samples of respondents from three groups within Qatar: Qatari citizens, white-collar expatriate households, and blue-collar expatriate households (i.e., labour camps). Interviews were conducted between February 21, 2011 and March 15, 2011. Altogether, 2,268 interviews were completed, including 800 Qatari nationals, 637 white-collar expatriates, and 831 blue-collar 
expatriates. To explore the effects of religiosity and social capital on civic engagement, we restrict our analysis to the data from the Qatari sample.

The Qatari sample is based on a stratified probability sampling framework. The state of Qatar is divided into seven administrative municipalities. Each municipality contains a number of zones and each zone is divided into several blocks. In the framework we adopted, there were 72 zones and 320 blocks. To assure representation of Qatari population in zones, proportionate stratified sampling was used whereby each zone was considered as one stratum. With the proportionate allocation, the sample in each stratum was selected with the same probabilities of selection. In each household, only one person 18 years or older was randomly selected for the survey. The within household sampling methodology we employed is developed by SESRI and has been found to fit very well with the Islamic culture in Qatar (Le et al. 2012). It ensured the representative nature of the survey without which the resulting samples would have been comprised of the 'most willing' and 'most readily available' persons (i.e. females, older adults, and those without employment since they are more available and more disposed towards cooperating with a survey request). The response rate was 61 percent for the Qatari sample and the completed survey responses were weighted before analysis to adjust for probability of selection and non-response.

The survey asked a variety of questions pertaining to civic engagement, which we use to capture our outcome measures. Respondents were asked whether they had made a donation to charitable organisations in the twelve months preceding the survey. They were also asked whether they had volunteered their time to organisations, such as charities or any other groups or organisations in the twelve months preceding the survey. These two variables are binary - one for positive answers, and zero for negative answers - and represent the two dependent variables used in our analysis.

Together, these measures capture the two principal ways in which individuals may contribute to civic organizations: donating their money or volunteering their time. Building on the pioneering work of Wilson, we think of donations and volunteering as part of a 'cluster of helping activities' (2000: 216). Wilson and Musick (1997) consider a variety of formal and informal 
volunteer activities, across which individuals decide how (and how much) time, effort or money to spend. There is an extensive literature that explores the rational calculus and cost-benefit analysis that underlies this choice (for review, see Wilson 2000). In their seminal work on civic participation in the US, Verba, Schlozman and Brady show that inequality in resources (e.g., money, time, education) plays a major role in explaining the various ways in which citizens choose to participate. While perhaps obvious, they find strong evidence that greater income strongly associates with increasing proclivity for donations (see also Li 2015a). In a rentier state like Qatar, this calculus is heavily influenced by the extreme resource wealth and inflated wages, which allow citizens to substitute donations for volunteering. Militating against this trend, however, there is also a broad social pressure to volunteer as a form of charity, which constitutes a pillar of Islam.

To evaluate the impact of religiosity and social capital on civic engagement among Qataris, we estimate a series of logistic regressions, using attitudinal and behavioral measures. We first consider the religiosity variables. Our attitudinal measure is a respondent's self-reported religiosity, which can take one of three values: 'Somewhat', 'Moderate', or 'Very'. We also consider a behavioral measure of religiosity, namely, whether an individual performs their fajr prayers daily. This is a dichotomous variable, splitting the sample into those respondents who report making their fajr prayers each day, and those who do not.

Prayer is one of the five pillars of Islam. Among the daily prayers, the fajr (or dawn) prayer is one of the most important and has a long tradition (Rubin 1987). The fajr prayer not only has a prominent place in Islam, but it also comes before sunrise, making its daily practice particularly onerous when compared to other prayers later in the day. Since fajr prayers are often conducted at the mosque, we assume that Muslims making these prayers regularly are more likely to be embedded in a congregation since they see their fellow parishioners at a regular time each day. And given the relative cost of making these prayers (coming early in the morning), we take these prayers as evidence of greater religiosity in terms of motivation, conscientiousness and selfdiscipline than simple mosque attendance (although it could be argued the other way round, namely, that more self-disciplined persons are more likely to attend daily morning prayers in the 
first place. Lacking panel data, we cannot fully address the 'selectivity' question here ${ }^{3}$ ). This should be especially true in a context like Qatar, where the citizen population is almost universally Muslim and reports attending a mosque.

In addition to the religious questions, respondents were also asked a series of questions which are intended to capture social capital and relative interconnectedness. The attitudinal measure comes from a generalized trust question, which asked respondents to take one position: 'Most people can be trusted' or 'You cannot be too careful when dealing with people'. Given these two responses, this trust question can be made into a simple binary variable for social trust, with responses coded as one for trust and zero otherwise. The behavioral measure of social capital comprises a three-part index. First, respondents were asked whether they had visited a neighbor during the week before the survey. Second, respondents were asked whether during the last six months they had talked to other people in their neighborhood about a local issue. And third, respondents were asked whether they had recently taken part in a neighborhood activity. The responses to these three questions were coded as one for 'yes' and zero for 'no' and were combined in a summative index, ranging from zero to three.

Finally, in addition to these measures for religiosity and social capital, we also include demographic variables as controls. These controls include the following: dummy variables for gender, employment, and marital status; continuous variables for age and income; and an ordinal measure for level of education (from zero to eight). Summary measures for these variables can be found in Table 1.

\section{Table 1: Descriptive Statistics}

\begin{tabular}{lccc}
\hline Variables & Observations & Mean & Standard Deviation \\
\hline Donations & 788 & 0.734 & 0.442 \\
Volunteering & 798 & 0.247 & 0.431 \\
Male & 800 & 0.404 & 0.491 \\
Age & 774 & 37.253 & 12.787 \\
Education & 791 & 4.244 & 1.889
\end{tabular}

${ }^{3}$ We wish to thank an anonymous reviewer for pointing this to us. 


\begin{tabular}{llcc} 
Married & 800 & 0.650 & 0.477 \\
Employed & 800 & 0.501 & 0.500 \\
Religiosity & 799 & 1.176 & 0.478 \\
Fajr & 792 & 0.617 & 0.486 \\
Trust & 797 & 0.201 & 0.401 \\
Social & 800 & 0.951 & 0.984 \\
Income & 512 & 33033 & 51234 \\
\hline
\end{tabular}

Collectively, these variables capture a variety of individual demographic characteristics that might influence someone's decision-making process to donate to charitable organizations and/or to volunteer his or her time to civic organizations. Along with the religiosity and social capital variables ${ }^{4}$, we use these variables to explore patterns of civic engagement in Qatar.

Before we introduce our empirical models and results, let us briefly sketch out our main predictions. Following from spillover theory, we would expect more religious individuals to be more civically active and engaged. Islam is a particularly communal religion, with daily prayer and regular activity built around the mosque. As such, religiously devout individuals will be more likely to participate in activities around the mosque and, as spillover theory would suggest, outside of it as well. Therefore, we would expect that, all things being equal, greater religiosity will be associated with an enhanced civic engagement (both in terms of charitable donations and volunteering).

A second and related question is how we could best measure religiosity or, to put it in more precise terms, whether attitudinal or behavioral indicators would best predict engagement. Although the attitudinal measure is ordinal and more granular than the dichotomous behavioral measure we use here, we may expect the latter to have a greater predictive effect when it comes to engagement. In other words, individuals who regularly pray Fajr on time should be more likely to participate in charitable organisations and other means of civic engagement. Given the importance of prayer time in Islam, individuals who regularly pray on time should, all things being equal, be

\footnotetext{
4 The correlation between the religiosity and social capital variables is as follow: religiosity \& trust (-0.0009); religiosity \& social capital (0.0157); Fajr \& trust (-0.0111); Fajr \& social capital (0.0718).
} 
more religiously devout. Serving as a behavioral proxy for religiosity, we may thus predict that individuals who pray on time are also more like to donate their money or give time to charitable organisations. After all, Islamic teachings strongly emphasize the neighbor, the neighborhood and the individual's obligation to help the poor and the needy. Therefore, those people who adhere to the teachings with regard to prayer time should be more likely to donate, volunteer and work with others in general, increasing their overall civic engagement. As Uslaner (2015) demonstrates, dichotomous treatment of ordinal variables gives a better indication of direction and effects of factors and avoids clumping.

Like religiosity, we would also expect social capital to have a positive effect on civic engagement. As social capital increases, individuals share a broader sense of community and interpersonal trust. In turn, individuals should be more inclined to participate in various civic organisations, volunteering time and giving money to some common enterprise. Yet how to capture this sense of shared community and network of trust in an effective way is a crucial matter. Recall that we have two measures for social capital, one of them being the attitudinal variable representing an individual's general sense of trust and the other being people's neighbourhood involvement. With regard to the first element, it is generally agreed by researchers that trust is closely related to civic engagement although there is disagreement as to which comes first. Putnam (2000), following Tocqueville (1835), holds that civic engagement engenders trust whereas Uslaner (2008) argues that trust is inherited and Li, Pickles and Savage (2005) show, using panel data, that generalised trust is 'classed' and that once prior levels of trust is held constant, civic engagement per se does not result in greater trust. Thus, people in higher socio-economic positions are enabled to take a trusting view towards the generalised others which leads them to take an active profile in civic engagement whilst working-class people tend to place greater trust in, and attachment to, their local communities. In spite of these debates, it is probably true that people who generally trust others are more likely to feel the need to give time and money to the needy and for communal goods. Uslaner, for instance, argues that "people who trust others see the world as a beneficent place and believe that they have an obligation to make it better. Some people have less, but they are part the same moral community as those who have more. Trusters thus see a moral 
obligation to help people with less' (2002: 241). An implication of Uslaner's argument is that trusters are generally well-to-do and can afford to be generous, a claim which is substantiated by existing research (Li, Pickles and Savage 2005). Yet it is equally the case that Muslims are more generous with their money than are the other religious groups in Britain, giving more in both absolute and relative terms, namely, in terms both of amounts and as a proportion of their incomes (Li 2015: 48). And this is particularly striking given the fact that they are the poorest group in the UK. Muslims in Britain are, of course, a small community. What role social trust plays on donation and civic volunteering in a Muslim majority country like Qatar is what we are going to investigate in this paper.

With regard to our second domain of social capital, we focus on people's neighborhood engagement which we believe may better capture their actual choices at a local level. And if engagement begins at the neighborhood level, we may expect this civic-mindedness to extend to other organisations. Overall, then, we may expect both domains of social capital to increase one's propensity to give time and money to a charitable organization or participate in other forms of civic engagement. But whether they do both or just give money in lieu of time is an empirical matter awaiting research as we are conducting in this paper, and the findings in this regard will have important implications both for social capital research and for policy-making.

\section{Methods and Results}

In testing the hypotheses from above, we estimate a series of logistic regressions. The data are shown in Tables 2 and 3. Table 2 presents the regression results, in terms of log odds, on donations to charitable organizations, followed by Table 3 on civic volunteering. For each dependent variable, we conduct nine models. The first three models include the demographic controls and the two religiosity variables, which are introduced separately, and then combined. The next three models replace the religiosity variables with the social capital measures, which are similarly introduced separately and then included in a single model. Model 7 combines both religiosity and social capital variables. Model 8 introduces a dummy variable for whether an 
individual volunteers (i.e., the outcome measure for the results in Table 3). Finally, Model 9 is identical to the last specification but also includes income ${ }^{5}$. Because slightly more than one third (36\%) of the respondents did not report household income, we use two variables for income in the regressions for model 9; a dummy variable for households reporting income (yes/no) and a continuous variable for income (which takes on the value of zero if the household income is not reported $)^{6}$.

${ }^{5}$ In the regression, we standardized the income variable by subtracting the mean and dividing by the standard deviation.

${ }^{6}$ We wish to thank the anonymous reviewer who suggested this treatment of the income variable to us. 


\begin{tabular}{|c|c|c|c|c|c|c|c|c|c|}
\hline Variables & Model1 & Model2 & Model3 & Model4 & Model5 & Model6 & Model7 & Model8 & Model9 \\
\hline Male & $\begin{array}{l}-0.549^{b} \\
(0.184)\end{array}$ & $\begin{array}{l}-0.555^{b} \\
(0.185)\end{array}$ & $\begin{array}{l}-0.557^{b} \\
0.185\end{array}$ & $\begin{array}{l}-0.532^{b} \\
(0.184)\end{array}$ & $\begin{array}{c}-0.586^{b} \\
0.184\end{array}$ & $\begin{array}{l}-0.568^{b} \\
(0.185)\end{array}$ & $\begin{array}{l}-0.588^{b} \\
(0.187)\end{array}$ & $\begin{array}{l}-0.535^{b} \\
(0.193)\end{array}$ & $\begin{array}{l}-0.555^{b} \\
(0.193)\end{array}$ \\
\hline Age & $\begin{array}{c}0.015^{\mathrm{a}} \\
(0.007)\end{array}$ & $\begin{array}{c}0.014 \\
(0.007)\end{array}$ & $\begin{array}{l}0.013 \\
0.008\end{array}$ & $\begin{array}{c}0.016^{\mathrm{a}} \\
(0.007)\end{array}$ & $\begin{array}{l}0.015^{\mathrm{a}} \\
0.007\end{array}$ & $\begin{array}{c}0.015^{\mathrm{a}} \\
(0.007)\end{array}$ & $\begin{array}{c}0.013 \\
(0.008)\end{array}$ & $\begin{array}{c}0.014 \\
(0.008)\end{array}$ & $\begin{array}{c}0.014 \\
(0.008)\end{array}$ \\
\hline Education & $\begin{array}{r}0.140^{b} \\
(0.049)\end{array}$ & $\begin{array}{c}0.151^{b} \\
(0.048)\end{array}$ & $\begin{array}{l}0.144^{b} \\
0.049\end{array}$ & $\begin{array}{r}0.144^{b} \\
(0.048)\end{array}$ & $\begin{array}{l}0.150^{b} \\
0.048\end{array}$ & $\begin{array}{c}0.147^{b} \\
(0.048)\end{array}$ & $\begin{array}{c}0.143^{b} \\
(0.049)\end{array}$ & $\begin{array}{c}0.124^{a} \\
(0.050)\end{array}$ & $\begin{array}{l}0.119^{a} \\
(0.050)\end{array}$ \\
\hline Married & $\begin{array}{c}0.159 \\
(0.193)\end{array}$ & $\begin{array}{c}0.139 \\
(0.194)\end{array}$ & $\begin{array}{l}0.138 \\
0.195\end{array}$ & $\begin{array}{c}0.156 \\
(0.194)\end{array}$ & $\begin{array}{l}0.141 \\
0.193\end{array}$ & $\begin{array}{c}0.137 \\
(0.194)\end{array}$ & $\begin{array}{c}0.124 \\
(0.196)\end{array}$ & $\begin{array}{c}0.159 \\
(0.203)\end{array}$ & $\begin{array}{c}0.208 \\
(0.207)\end{array}$ \\
\hline Employed & $\begin{array}{c}0.652^{c} \\
(0.196)\end{array}$ & $\begin{array}{c}0.679^{c} \\
(0.197)\end{array}$ & $\begin{array}{l}0.680^{c} \\
0.197\end{array}$ & $\begin{array}{l}0.664^{c} \\
(0.195)\end{array}$ & $\begin{array}{l}0.625^{b} \\
0.195\end{array}$ & $\begin{array}{c}0.641^{b} \\
(0.196)\end{array}$ & $\begin{array}{c}0.663 \\
(0.198)\end{array}$ & $\begin{array}{c}0.573^{b} \\
(0.203)\end{array}$ & $\begin{array}{l}0.594^{b} \\
(0.204)\end{array}$ \\
\hline Religiosity & $\begin{array}{l}-0.145 \\
(0.177)\end{array}$ & & $\begin{array}{l}-0.183 \\
(0.180)\end{array}$ & & & & $\begin{array}{l}-0.206 \\
(0.183)\end{array}$ & $\begin{array}{l}-0.170 \\
(0.187)\end{array}$ & $\begin{array}{l}-0.179 \\
(0.187)\end{array}$ \\
\hline Fajr & & $\begin{array}{c}0.302 \\
(0.183)\end{array}$ & $\begin{array}{c}0.321 \\
(0.183)\end{array}$ & & & & $\begin{array}{c}0.280 \\
(0.185)\end{array}$ & $\begin{array}{c}0.158 \\
(0.194)\end{array}$ & $\begin{array}{c}0.159 \\
(0.195)\end{array}$ \\
\hline Trust & & & & $\begin{array}{l}-0.167 \\
(0.214)\end{array}$ & & $\begin{array}{l}-0.215 \\
(0.216)\end{array}$ & $\begin{array}{l}-0.162 \\
(0.219)\end{array}$ & $\begin{array}{l}-0.141 \\
(0.223)\end{array}$ & $\begin{array}{l}-0.158 \\
(0.227)\end{array}$ \\
\hline $\begin{array}{l}\text { Neighbourhood } \\
\text { involvement }\end{array}$ & & & & & $\begin{array}{c}0.250^{b} \\
(0.091)\end{array}$ & $\begin{array}{l}0.261^{b} \\
(0.092)\end{array}$ & $\begin{array}{c}0.265^{b} \\
(0.092)\end{array}$ & $\begin{array}{r}0.212^{\mathrm{a}} \\
(0.094)\end{array}$ & $\begin{array}{l}0.233^{a} \\
(0.096)\end{array}$ \\
\hline Volunteering & & & & & & & & $\begin{array}{c}2.269^{c} \\
(0.379)\end{array}$ & $\begin{array}{l}2.272^{c} \\
(0.380)\end{array}$ \\
\hline $\begin{array}{l}\text { Reporting } \\
\text { income (yes) }\end{array}$ & & & & & & & & & $\begin{array}{l}-0.284 \\
(0.199)\end{array}$ \\
\hline Income & & & & & & & & & $\begin{array}{c}0.173 \\
(0.152)\end{array}$ \\
\hline Intercept & $\begin{array}{l}-0.155 \\
(0.424)\end{array}$ & $\begin{array}{l}-0.480 \\
(0.360)\end{array}$ & $\begin{array}{l}-0.233 \\
(0.427)\end{array}$ & $\begin{array}{l}-0.341 \\
(0.357)\end{array}$ & $\begin{array}{l}-0.527 \\
(0.364)\end{array}$ & $\begin{array}{l}-0.511 \\
(0.364)\end{array}$ & $\begin{array}{l}-0.353 \\
(0.437)\end{array}$ & $\begin{array}{l}-0.546 \\
(0.450)\end{array}$ & $\begin{array}{l}-0.361 \\
(0.463)\end{array}$ \\
\hline $\mathrm{N}$ & 756 & 751 & 750 & 755 & 757 & 755 & 748 & 748 & 748 \\
\hline
\end{tabular}

${ }^{\mathrm{a}} \mathrm{p}<.0 .05,{ }^{\mathrm{b}}<0.01,{ }^{\mathrm{c}} \mathrm{p}<.001$

Notes: Survey weights used. Standard errors in parentheses. 
As seen in Table 2, the male indicator, employment status, and education variables are all largely significant across the models. These results broadly suggest that Qataris who are women, employed, and educated are more likely to donate to charitable organizations. Surprisingly, contrary to our expectations and the general empirical support for spill-over theory, we find little evidence that religiosity plays a major role in charitable donations. Across all nine models, the attitudinal and behavioral measures for religiosity turn out to be insignificant. Neither variable is associated with an increased propensity to donate. This pattern is, however, not found when we consider the impact of social capital on donation. We see strong and consistent evidence that social capital matters, albeit only with respect to the behavioral measure on neighborhood engagement. This behavioral measure is positive and significant across all relevant models.

Turning now to volunteerism (see table 3 ) which we include to capture potential substitution effects between charitable donations (i.e., money) and volunteering (i.e., time), we find that including this variable helps us in evaluating whether Qataris who choose to volunteer their time are less likely to donate money to charitable causes. If this were the case, it could have worrisome welfare implications, with individuals trading-off their time for money. The results from columns eight and nine strongly suggest otherwise. The positive and highly significant coefficient on volunteering indicates that those individuals who report giving time to voluntary activities are also more likely to donate money. There is thus no evidence of substitution effects in this regard.

Surprisingly, we find in model 9 that neither of the variables representing household income had significant effects on volunteering or donation. In other words, households reporting income are not significantly different from those which did not report household income and, furthermore, the level of income reported shows no significant bearing on charitable donation or volunteering. 


\begin{tabular}{|c|c|c|c|c|c|c|c|c|c|}
\hline Variables & Modell & Model2 & Model3 & Model4 & Model5 & Model6 & Model7 & Model8 & Model9 \\
\hline Male & $\begin{array}{l}-0.301 \\
(0.182)\end{array}$ & $\begin{array}{l}-0.288 \\
(0.187)\end{array}$ & $\begin{array}{l}-0.281 \\
(0.187)\end{array}$ & $\begin{array}{l}-0.293 \\
(0.181)\end{array}$ & $\begin{array}{l}-0.375^{a} \\
(0.185)\end{array}$ & $\begin{array}{l}-0.354 \\
(0.184)\end{array}$ & $\begin{array}{l}-0.330 \\
(0.188)\end{array}$ & $\begin{array}{l}-0.223 \\
(0.200)\end{array}$ & $\begin{array}{l}-0.222 \\
(0.200)\end{array}$ \\
\hline Age & $\begin{array}{c}0.007 \\
(0.008)\end{array}$ & $\begin{array}{c}0.0002 \\
(0.008)\end{array}$ & $\begin{array}{c}0.001 \\
(0.008)\end{array}$ & $\begin{array}{c}0.008 \\
(0.008)\end{array}$ & $\begin{array}{c}0.005 \\
(0.008)\end{array}$ & $\begin{array}{c}0.007 \\
(0.008)\end{array}$ & $\begin{array}{c}0.001 \\
(0.008)\end{array}$ & $\begin{array}{l}-0.002 \\
(0.009)\end{array}$ & $\begin{array}{l}-0.003 \\
(0.009)\end{array}$ \\
\hline Education & $\begin{array}{c}0.113^{a} \\
(0.049)\end{array}$ & $\begin{array}{c}0.112^{a} \\
(0.050)\end{array}$ & $\begin{array}{c}0.109^{a} \\
(0.051)\end{array}$ & $\begin{array}{c}0.113^{a} \\
(0.049)\end{array}$ & $\begin{array}{c}0.119^{a} \\
(0.050)\end{array}$ & $\begin{array}{c}0.12 \\
(0.050)\end{array}$ & $\begin{array}{c}0.117^{a} \\
(0.052)\end{array}$ & $\begin{array}{c}0.088 \\
(0.054)\end{array}$ & $\begin{array}{c}0.084 \\
(0.055)\end{array}$ \\
\hline Married & $\begin{array}{l}-0.078 \\
(0.201)\end{array}$ & $\begin{array}{l}-0.073 \\
(0.203)\end{array}$ & $\begin{array}{l}-0.083 \\
(0.203)\end{array}$ & $\begin{array}{l}-0.082 \\
(0.201)\end{array}$ & $\begin{array}{l}-0.090 \\
(0.204)\end{array}$ & $\begin{array}{l}-0.103 \\
(0.205)\end{array}$ & $\begin{array}{l}-0.106 \\
(0.207)\end{array}$ & $\begin{array}{l}-0.176 \\
(0.213)\end{array}$ & $\begin{array}{l}-0.175 \\
(0.212)\end{array}$ \\
\hline Employed & $\begin{array}{c}0.530^{b} \\
(0.186)\end{array}$ & $\begin{array}{c}0.557^{b} \\
(0.190)\end{array}$ & $\begin{array}{c}0.562^{b} \\
(0.190)\end{array}$ & $\begin{array}{c}0.523^{b} \\
(0.187)\end{array}$ & $\begin{array}{c}0.510^{b} \\
(0.190)\end{array}$ & $\begin{array}{c}0.507^{b} \\
(0.190)\end{array}$ & $\begin{array}{c}0.532^{b} \\
(0.193)\end{array}$ & $\begin{array}{c}0.404 \\
(0.208)\end{array}$ & $\begin{array}{c}0.386 \\
(0.208)\end{array}$ \\
\hline Religiosity & $\begin{array}{l}-0.135 \\
(0.180)\end{array}$ & $\begin{array}{c}0.597 \\
(0.194)\end{array}$ & $\begin{array}{l}-0.210 \\
(0.183)\end{array}$ & & & & $\begin{array}{l}-0.199 \\
(0.182)\end{array}$ & $\begin{array}{l}-0.163 \\
(0.196)\end{array}$ & $\begin{array}{l}-0.165 \\
(0.197)\end{array}$ \\
\hline Fajr & & $\begin{array}{c}0.597^{b} \\
(0.194)\end{array}$ & $\begin{array}{c}0.605^{b} \\
(0.195)\end{array}$ & & & & $\begin{array}{c}0.566^{b} \\
(0.197)\end{array}$ & $\begin{array}{c}0.525^{\mathrm{a}} \\
(0.205)\end{array}$ & $\begin{array}{c}0.540^{b} \\
(0.204)\end{array}$ \\
\hline Trust & & & & $\begin{array}{l}-0.239 \\
(0.227)\end{array}$ & & $\begin{array}{l}-0.299 \\
(0.228)\end{array}$ & $\begin{array}{l}-0.238 \\
(0.230)\end{array}$ & $\begin{array}{l}-0.205 \\
(0.236)\end{array}$ & $\begin{array}{l}-0.209 \\
(0.236)\end{array}$ \\
\hline $\begin{array}{l}\text { Neighbourhood } \\
\text { involvement }\end{array}$ & & & & & $\begin{array}{c}0.283^{c} \\
(0.084)\end{array}$ & $\begin{array}{l}0.288^{\mathrm{C}} \\
(0.083)\end{array}$ & $\begin{array}{c}0.277^{b} \\
(0.084)\end{array}$ & $\begin{array}{c}0.219^{a} \\
(0.088)\end{array}$ & $\begin{array}{l}0.216^{a} \\
(0.089)\end{array}$ \\
\hline Donating & & & & & & & & $\begin{array}{r}2.266^{c} \\
(0.377)\end{array}$ & $\begin{array}{c}2.266^{c} \\
(0.380)\end{array}$ \\
\hline $\begin{array}{l}\text { Reporting } \\
\text { Income } \\
\text { (yes/no) }\end{array}$ & & & & & & & & & $\begin{array}{c}0.108 \\
(0.199)\end{array}$ \\
\hline Income & & & & & & & & & $\begin{array}{c}0.069 \\
(0.100)\end{array}$ \\
\hline Intercept & $\begin{array}{l}-1.870^{c} \\
(0.445)\end{array}$ & $\begin{array}{l}-2.178^{c} \\
(0.406)\end{array}$ & $\begin{array}{l}-1.940^{C} \\
(0.458)\end{array}$ & $\begin{array}{l}-2.000^{c} \\
(0.390)\end{array}$ & $\begin{array}{l}-2.227^{c} \\
(0.404)\end{array}$ & $\begin{array}{l}-2.228^{C} \\
(0.405)\end{array}$ & $\begin{array}{l}-2.161^{c} \\
(0.471)\end{array}$ & $\begin{array}{l}-3.708^{c} \\
(0.612)\end{array}$ & $\begin{array}{l}-3.72^{c} \\
(0.625)\end{array}$ \\
\hline $\mathrm{N}$ & 765 & 758 & 757 & 763 & 766 & 763 & 754 & 748 & 748 \\
\hline
\end{tabular}

${ }^{\mathrm{a}} \mathrm{p}<.0 .05,{ }^{\mathrm{b}}<0.01,{ }^{\mathrm{c}} \mathrm{p}<.001$

Notes: Survey weights used. Standard errors in parentheses. 
Moving now to people's propensity to volunteer as shown in Table 3, we find that only employment and education have consistently significant results in a general manner. But even these variables lose their significance in the last two models. Overall, the results are substantively similar to those from Table 2, with employed and higher educated Qataris more likely to volunteer. When we turn to the religiosity variables, however, we see a much different pattern. In the previous models, there was scant evidence that religious beliefs or behaviors increased a respondent's likelihood to donate. Now we see strong evidence that the behavioral measure for religiosity is positively associated with volunteering. Qataris who report making their Fajr prayers on time are significantly more likely to have volunteered with an organization. At least when it comes to volunteering, we see evidence consistent with spillover theory. The only column for which we do not find this effect is Model 9, which includes the income measure. Income itself is positively, albeit not significantly, associated with volunteering and, given missing data on this variable, its inclusion reduces the sample size by nearly a third, significantly decreasing power for the analysis.

As for the social capital measures, we see the same general pattern with volunteering as we did with donations: the behavioral measure is positive and significant across most models, but the trust variable is not. Qataris who visit their neighbors, discuss neighborhood issues, or take part in a neighborhood activity are more likely to volunteer their time to organisations. Trust plays no significant role on Qataris' decision to volunteer despite the fact that it has been considered as a key component of social capital. Overall, the results from Tables 2 and 3 strongly suggest that behavioral indicators are more determinative than simple attitudinal variables.

Finally, we see that the donation variable is positive and highly significant in the eighth and ninth columns. This result further suggests that there is no substitution effect when it comes to volunteering and donations. If anything, we find strong evidence that those individuals who are generous with their money are equally pro-social in giving their valuable time to civic activities. The two domains of civic-mindedness reinforce each other. 


\section{Conclusion}

We have, in this paper, sought to contribute to social capital research in a Muslim-majority context. Social capital has caught the imagination of social scientists in various social science disciplines but most of the research has been conducted on the mainstream populations in the USA and Europe. In a rapidly changing world with much Islamophobia running about, it is of particular importance to ask whether citizens in a Muslim-majority country would exhibit social capital, whether aspects of pro-social behaviours such as donating to charitable causes or volunteering to civic activities would complement or substitute each other, and whether the main determinants of such generosity would be similar in such a context as in the western countries. To address such questions, we used purposefully-designed surveys in Qatar with very high quality. Our results can be summarized as follows.

Firstly, we found that religiosity and social connectedness as indicated by neighbourhood involvement have a significant and independent effect on Qataris' decisions to donate to charitable organizations and to volunteer to organizations, such as charities and other groups. For instance, morning prayers are shown (Table 3) to have a significant net impact on volunteering which is also seen to have an independent and significant effect on donation (Table 2). In this sense, the spill-over effect is demonstrated, namely, the more devout Muslims are more civicly engaged in other civic organisations which also fosters in them the sense of a pro-social aptitude by actively giving their treasures to the needy and for good causes. The findings in this regard actually indicate something more than a spill-over effect, but a complementary effect as Putnam (2000) discusses in detail. There is no substitution effect as the civic-minded Qataris did not see giving money could replace giving time for voluntary activities, and vice versa. While active political participation may not be highly possible in Qatar, the Government should encourage its citizens to maintain and even develop their prosocial behaviours.

Secondly, with regard to the determinants of pro-social behaviours (donation and volunteering in our case), we found that the role of behavioral variables is much more important than that of attitudinal ones. Praying fajr on time, and being active in neighborhood activities weigh 
more on Qataris' decisions to donate to charitable organizations and to volunteer than simply being religious or holding a trusting view. With regard to trust, our findings lend support to research in Britain (Li, Pickles and Savage 2005).

Thirdly, we found that, with regard to both donation and volunteering, education and employment plays a highly important and positive role. Highly educated people are usually found in higher social (class) and economic positions, and high education in itself also denotes high levels of human and cultural capital, which foster sympathy, understanding and a more cosmopolitan perspective and which serve as foundation stones of pro-social behaviour. In this sense, social, economic and cultural capitals are mutually reinforcing in the Qatari context as in other countries (Hall 1999; Li, Savage and Pickles 2003; Li, Savage and Warde 2015). In other words, Muslim societies, at least in the case of Qatar, are no exception in so far as determinants of social capital are concerned.

Overall, the evidence as we have found in this paper not only sheds light on civic engagement in a Muslim-majority, Gulf, country, but also has important implications for the broader literature on social capital. It has been argued that the relationship between social trust and participation in community building is a reciprocal one, with social trust leading to more participation and more participation leading to more trust. However, Smidt (1999) has found no such relationship in his comparative analysis of civic engagement and trust for Americans and Canadians, nor is such a relationship found in the British context (Li, Pickles and Savage 2005). Other researchers, such as Brehm and Rahn (1997), have emphasized the dominant effect of participation on trust. Our finding that trust plays no significant impact on civic engagement may well provide support to arguments that social trust and civic engagement are not as closely related (Guterbock and Fries 1997). In other words, generalized social trust may well be a product of socialization and advantaged socio-economic position.

In terms of policy implications, we believe that our findings of the positive effects of religiosity and neighbourhood involvement on Qataris' decision to donate to charitable organizations and to volunteer to organizations could be useful for authorities interested in making the country more welcoming and more inclusive in a context of a heterogeneous expatriate 
population which outnumbers that of the nationals. While it would be difficult to increase people's level of trust (Li, Pickles and Savage, 2005; Uslaner, 2008), it would be more feasible to enhance social capital at the neighbourhood level. Equally important are the role of education and employment. For a country so rich in GDP, the government is in a unique position to enhance the citizens' educational and employment levels. 


\section{References}

Beblawi, H. (1987). "The rentier state in the Arab world." Arab Studies Quarterly, 383-398.

Bekkers, R., \& Schuyt, T. (2008). "And who is your neighbor? Explaining denominational differences in charitable giving and volunteering in the Netherlands." Review of Religious Research, 74-96.

Beyerlein, K., \& Hipp, J. R. (2005). "Social capital, too much of a good thing? American religious traditions and community crime." Social Forces, 84(2): 995-1013.

Bloom, P. B. N., \& Arikan, G. (2012). A two-edged sword: The differential effect of religious belief and religious social context on attitudes towards democracy. Political Behavior, 34(2): 249-276.

Brehm, J., \& Rahn, W. (1997). "Individual-level evidence for the causes and consequences of social capital.” American Journal of Political Science, 999-1023.

Central Intelligence Agency. (2014). Qatar. In The World Factbook.

Coleman, J. S. (1988). "Social capital in the creation of human capital." American Journal of Sociology, S95-S120.

Colletta, N. J., \& Cullen, M. L. (2000). "Violent conflict and the transformation of social capital: Lessons from Cambodia, Rwanda, Guatemala, and Somalia (Vol. 795).” World Bank Publications.

Dana, K., Barreto, M. A., \& Oskooii, K. A. (2011). "Mosques as American institutions: Mosque attendance, religiosity and integration into the political system among American Muslims." Religions, 2(4): 504-524.

de Tocqueville, A. (1835). Democracy in America. New York: Vintage.

Gardner, A. M. (2011). "Gulf migration and the family.” Journal of Arabian Studies, 1(1): 3-25.

Gengler, J., Tessler, M., Al-Emadi, D., \& Diop, A. (2013). “Civic Life and Democratic Citizenship in Qatar Findings from the First Qatar World Values Survey." Middle East Law and Governance, 5(3): 258-279. 
Gill, A., \& Lundsgaarde, E. (2004). "State welfare spending and religiosity a cross-national analysis." Rationality and Society, 16(4): 399-436.

Greeley, A. (2001). "The future of religion in America.” Society, 38(3): 32-37.

Grootaert, C., \& Van Bastelaer, T. (2001). "Understanding and measuring social capital: A synthesis of findings and recommendations from the social capital initiative (Vol. 24)." World Bank, Social Development Family, Environmentally and Socially Sustainable Development Network.

Guterbock, T. M., \& Fries, J. C. (1997). "Maintaining America's social fabric: The AARP survey of civic involvement." Washington, DC: American Association of Retired Persons.

Inglehart, R. (1997). "Modernization and postmodernization: Cultural, economic, and political change in 43 societies (Vol. 19)." Princeton, NJ: Princeton University Press.

Jamal, A. (2005). "The political participation and engagement of Muslim Americans'mosque involvement and group consciousness.” American Politics Research, 33(4): 521-544.

Hall, P. (1999) 'Social Capital in Britain', British Journal of Political Science, 29: 417-461.

Kamrava, M. (2012). Political Economy of the Persian Gulf. Hurst Publishers.

Lam, P. Y. (2002). “As the flocks gather: How religion affects voluntary association participation.” Journal for the Scientific Study of Religion, 405-422.

Langohr, V. (2004). "Too much civil society, too little politics: Egypt and liberalizing Arab regimes." Comparative politics, 181-204.

Le, T., Kien, J. M., Brick, A., \& Diop, D. A. (2013). Within household sampling conditioning on household size. International Journal of Public Opinion Research, 25, 108-118.

Li, Y. (2015a) 'The flow of soul: a sociological study of generosity in England and Wales (2001 - 2011)', in Li, Y. (ed.) The Handbook of Research Methods and Applications on Social Capital, Cheltenham: Edward Elgar Publishing, pp: 40-59.

Li, Y. (2015b) 'Social capital in sociological research: conceptual rigour and empirical application', in Li, Y. (ed.) The Handbook of Research Methods and Applications on Social Capital, Cheltenham: Edward Elgar Publishing, pp: 1-20. 
Li, Y., Pickles, A. and Savage, M. (2005) 'Social Capital and Social Trust in Britain', European Sociological Review, 21(2): 109-123.

Li, Y., Savage, M. and Pickles, A. (2003) 'Social Capital and Social Exclusion in England and Wales (1972-1999)', British Journal of Sociology, 54(4): 497-526.

Li, Y., Savage, M. and Warde, A. (2015) 'Social stratification, social capital and cultural practice in the UK', in Li, Y. (ed.) The Handbook of Research Methods and Applications on Social Capital, Cheltenham: Edward Elgar Publishing, pp: 21-39.

Lim, C., \& Putnam, R. D. (2010). Religion, social networks, and life satisfaction. American Sociological Review, 75(6): 914-933.

Miller, A. H., \& Wattenberg, M. P. (1984). "Politics from the Pulpit: Religiosity and the 1980 Elections." Public Opinion Quarterly, 301-317.

Montagu, C. (2010). 'Civil society and the voluntary sector in Saudi Arabia'. The Middle East Journal, 64(1): 67-83.

Musick, M. A., Wilson, J., \& Bynum, W. B. (2000). 'Race and formal volunteering: The differential effects of class and religion'. Social Forces, 78(4): 1539-1570.

Nagy, S. (2006). "Making room for migrants, making sense of difference: Spatial and ideological expressions of social diversity in urban Qatar." Urban Studies, 43(1): 119-137.

Norris, P., \& Inglehart, R. (2002). "Islamic culture and democracy: Testing the 'clash of civilizations' thesis." Comparative Sociology, 1(3): 235-263.

Okruhlik, G. (1999). "Rentier wealth, unruly law, and the rise of opposition: the political economy of oil states." Comparative Politics, 295-315.

Paxton, P. (1999). "Is social capital declining in the United States? A multiple indicator assessment.” American Journal of Sociology, 105(1): 88-127.

Peterson, S. A. (1992). "Church Participation and Political Participation: The Spillover Effect." American Politics Quarterly, 20(1): 123-139.

Pfaff, S., \& Gill, A. J. (2006). "Will a million Muslims march? Muslim interest organizations and political integration in Europe." Comparative Political Studies, 39(7): 803-828. 
Putnam, R. (2000). "Bowling alone, the collapse and revival of civic America." New York: Simon $\&$ Schuster.

Putnam, R. D. (2007) 'E Pluribus Unum: Diversity and Community in the Twenty-first Century, The 2006 Johan Skytte Prize Lecture', Scandinavian Political Studies, 33(2): 137-74.

Putnam, R. D., Campbell, D. E. and Garrett, S. R. (2012) American Grace: How Religion Divides and Unites Us, New York: Simon \& Schuster.

Ringgren, H. (2014). “The problems of syncretism.” Scripta Instituti Donneriani Aboensis, 3: 714.

Rubin, U. (1987). “Morning and evening prayers in early Islam.” JSAI, 10: 40-67.

Ruiter, S., \& De Graaf, N. D. (2006). "National context, religiosity, and volunteering: Results from 53 countries." American Sociological Review, 71(2): 191-210.

Sarkissian, A. (2012). "Religion and civic engagement in Muslim countries." Journal for the Scientific Study of Religion, 51(4): 607-622.

Schofer, E., \& Fourcade-Gourinchas, M. (2001). "The structural contexts of civic engagement: Voluntary association membership in comparative perspective." American Sociological Review, 806-828.

Schwadel, P. (2005). 'Individual, congregational, and denominational effects on church members' civic participation." Journal for the Scientific Study of Religion, 44(2): 159-171.

Schwarz, R. (2008). "The political economy of state-formation in the Arab Middle East: Rentier states, economic reform, and democratization." Review of International Political Economy, 15(4): 599-621.

Shah, N. M. (2013). "Labour Migration from Asian to GCC Countries: Trends, Patterns and Policies." Middle East Law and Governance, 5(1-2): 36-70.

Smidt, C. (1999). "Religion and civic engagement: A comparative analysis." The Annals of the American Academy of Political and Social Science, 565(1): 176-192.

Sobh, R., \& Belk, R. (2011). "Domains of privacy and hospitality in Arab Gulf homes.” Journal of Islamic Marketing, 2(2): 125-137. 
Sommer, U., Bloom, P. B. N., \& Arikan, G. (2013). Does faith limit immorality? The politics of religion and corruption. Democratization, 20(2), 287-309.

Uslaner, E. M. (2002). The moral foundations of trust. Cambridge: Cambridge University Press.

Uslaner, E.M. (2008) 'Where you stand depends upon where your grandparents sat: The inheritability of generalized trust,' Public Opinion Quarterly 72(4): 725-740.

Uslaner, E. (2015) 'The rootes of trust', in Li, Y. (ed.) The Handbook of Research Methods and Applications on Social Capital, Cheltenham: Edward Elgar Publishing. pp: 60-75.

Verba, S., Schlozman, K. L., Brady, H. E., \& Brady, H. E. (1995). Voice and equality: Civic voluntarism in American politics (Vol. 4). Cambridge, MA: Harvard University Press.

Wilson, J. (2000). "Volunteering." Annual review of sociology, 215-240.

Wilson, J., \& Musick, M. (1997). "Who cares? Toward an integrated theory of volunteer work." American Sociological Review, 694-713.

Wuthnow, R. (1999). "Mobilizing civic engagement: The changing impact of religious involvement." Civic engagement in American Democracy, 331-363.

Wuthnow, R. (2003). “The Impact of Religious Involvement on Civic Life.” In United We Serve: National Service and the Future of Citizenship. E. J. Dionne Jr. and K. Meltzer Dorgosz and E.R. Litan (eds.). Washington, DC: Brookings University Press, pp. 222-237. 